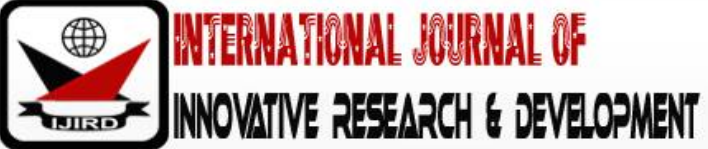

ISSN 2278-0211 (Online)

\section{Effects of Time Management on Organizational Efficiency: A Study of Tonimas Nigerian. Ltd Aba, Abia State, Nigeria}

\author{
Dr. Melletus Uchechukwu Agbo \\ Lecturer, Department of Business Administration, \\ Michael Okpara University of Agriculture, Umudike, Abia State, Nigeria
}

\begin{abstract}
:
The study examined the effects of time management on organizational efficiency ( $A$ Study of TONIMAS Nig. Ltd Aba, Abia State.)Time management can be described as the art of planning a job, measuring such activities to time element (expressed in terms of pieces per unit or time per piece) and monitoring it to determine efficiency and productivity. The researcher adopted the survey design, using simple random sampling techniques, descriptive statistics and inferential statistics. A total number of eighty-four (84) questionnaire were issued out by the researcher to the staff and customers of TONIMAS Nig. Ltd Aba, Abia State. The coefficient of determination R-square of 0.823 implied $82.3 \%$ of the sample variation in the dependent variable, degree of relationship between time management and organizational efficiency of TONIMAS Nig. Plc. Aba. The value of the adjusted $R^{2}$ was 0.817. This showed that the regression line which captured 81.7\% of the total variation in degree of relationship between time management and organizational efficiency of TONIMAS Nig. Plc. Aba. The F-value of 137.191 was an indication that the model was statistically significant at 5 percent level of significant at degree of freedom $d f 1=2$ and $d f 2=59$.The calculated $t$-statistics of 7.774 was greater than the critical value (i.e.2.000), the null hypothesis was rejected and the alternate accepted. The findings indicated that there was significant relationship between managerial planning/scheduling and profitability of TONIMAS Nig. Ltd Aba, Abia State, as shown in3.9.2 where the result of the analysis revealed that the Calculated $t$-value of 7.774 was greater than the table value (2.000), therefore, the null $\left(H_{0}\right)$ hypothesis was rejected, while the alternate hypothesis $\left(H_{1}\right)$ accepted. This implies that there was significant relationship between managerial planning/scheduling and profitability of TONIMAS Nig. Ltd Aba, Abia state.
\end{abstract}

Keywords: Organization, time management, productivity, profitability, performance

\section{Introduction}

\subsection{Background of the Study}

Time management is the process of planning and exercising conscious control of time spent on specific activities, especially to increase effectiveness, efficiency or productivity. It is a juggling act of various demands of study, social life, employment, family, and personal interests and commitments with the finiteness of time. Using time effectively gives the person 'choice' on spending/ managing activities at their own time and expediency.

Time management is the managing of your time so that time is used to your advantage and it gives you a chance to spend your most valuable resource in the way you choose. Time management is a skill that can be learned which involves techniques for prioritizing activities and using time effectively while eliminating disruptions and time wasters (Researcher, 2018). Time Management is an endless series of decisions, small and large, that gradually change the shape of your life. A time management system is a designed combination of processes, tools, techniques, and methods. Time management is usually a necessity in any project development as it determines the project completion time and scope. The major themes arising from the literature on time management include the following:

- Creating an environment conducive to effectiveness

- Setting of priorities

- Carrying out activity around prioritization.

- The related process of reduction of time spent on non-priorities

- Incentives to modify behavior to ensure compliance with time-related deadlines.

Time management is one of the components of management science, time management is the effective use of resources and it is a way to attain personal goals. In addition, time management involves skill such as personal discipline, targeting, intervals controlling, organizing method and etc. these skills can lead to elimination of many stress-induced conditions (Mehran, Hamid and Leila, 2015). There are definitions for time management similar to the ones provided for humanity literary terms. Gerikez indicates that time management is those skills and capabilities that can results in better time controlling by the individual (Louis, 2003). Sorush believes that time management is providing effective scientific methods and controlling it in order to attain higher levels of success in job and life. These methods involve targeting, 
determining priorities, and observing the priorities (Mehran, Hamid and Leila, 2015)

Time management is a set of skills that assists people in using time effectively. There are general guidelines that can be employed for time management in different fields such as house, school, and job. A number of these guidelines are provided here. Initially, the reasons of not using tie management and the benefits derived from time management are studied. Probably, the most obvious reason for not using the time management is that people are not aware of the concept 'time management'. The second reason is laziness. Some people lack any effective target and required motivation for effective planning. The third group who do not make use of time management is the ones who tend to work under the pressure conditions (SadegGorji, 2006). It is probable that not using of time management is justifiable, but successfi.il usage of time management rejects any justified reason. Time management helps people in determining what task get priority over the others. Also, tie management assists people to increase the real work time through removing inessential activities. One of the satisfactory aspects of time management is reducing stress in life. Decrease of stress level leads to increased physical and spiritual health (Makcnzi, 2006).

Organizational effectiveness is regarded as attaining the priorities and multi-dimensional goals within the common valuable framework so that achieving goals is efficient in terms of time and expense.

\subsection{Statement of the Problem}

One of the main reasons for the continuing underdevelopment of African countries is our nonchalant attitude to time and the need for punctuality in all aspects of life. The problem of punctuality has become so endemic that lateness to any functions is accepted and explained off as 'African time'. It is against this background that time management in public administration or private sector organization in Nigeria is so crucial.

Time, as a key critical resource in every organization especially in TONIMAS Nigerian Limited must be managed carefully and judiciously because of its limitations, importance and non- recoverable character, in order to maximize productivity and better customer services. To proffer solution to the identified problem motivated the researcher to carry out this study.

\subsection{Objective of the Study}

The main objective of the study is to examine the effect of time management on organizational efficiency of Tonimas Nig. Ltd Aba, Abia State. With specific objectives as to;

- Examine the relationship between time management on organizational productivity of Tonimas Nig. Ltd Aba, Abia State.

- Determine the impact of managerial planning/scheduling on profitability of Tonimas Nig. Ltd Aba, Abia state.

\subsection{Research Questions}

The following research questions were formulated for the study;

- What is the relationship between time management and organizational productivity of Tonimas Nig. Ltd Aba, Abia State?

- To what extent does managerial planning/scheduling affects the profitability of Tonimas Nig. Ltd Aba, Abia State?

\subsection{Research Hypotheses}

The following research hypotheses were formulated for the study;

- There is positive and significant relationship between time management and organizational productivity of Tonimas Nig. Ltd Aba, Abia State.

- There is positive and significant relationship between managerial planning/scheduling and profitability of Tonimas Nig. Ltd Aba, Abia State.

\section{Revive of Related Literature}

\subsection{Conceptual Framework}

Time management is the managing of your time so that time is used to your advantage and it gives you a chance to spend your most valuable resource in the way you choose. Time management is a skill that can be learned which involves techniques for prioritizing activities and using time effectively while eliminating disruptions and time wasters. Time Management is an endless series of decisions, small and large, that gradually change the shape of your life (Kotla, 2013). Time management is one of the effective ways to improve efficiency and books of management and organizational behavior place great emphasis on it. This type of management helps avoid unnecessary work, organization, delegation and finally increases efficiency. Time management is not something distinct and separate from management in a general sense and its purpose is to avoid wasting time and discipline work time

(Hashemizade, 2016). In fact, time wasting is one of the main reasons for reduced performance of staff and especially managers in the work environment and it should be analyzed in the field of time management. When it comes to time wasting, the time spent on relaxing or entertainment comes to mind. But, in fact, these times are not wasted; rather they are opportunities for relaxation and recuperation in order to prepare to work (Bagheri andYousefinezhad, 2012). Time wasting refers to working hours during which the manager appears to work, goes by without a goal, like the time spent on checking the desk for files. Of course not all time wastes are apparent like this. Most of the time a manager, without realizing, spends his time doing unnecessary work (Negahban, 2015).

Taheri and Haghighi (2011) have examined the relationship between time management and productivity of 
Telecom executives of Shiraz. In this study which is correlational, two questionnaires were used. The first questionnaire measures the amount of time management skills and its six dimensions, and the second questionnaire measures the productivity of human resources. The results of this research indicate that there is a significant direct relation between time management skills (targeting, prioritization of goals, operational planning and delegating, managing contacts and meetings) and productivity of managers.

\subsubsection{Time and Time Management Concept}

Under the term time management we mean organization, distribution and duration of work indifferent periods such as day, week, month, or year. What is time? Some even say that time does not exist because the past is unreachable, the future is unknown, and the present is immeasurable, which is an interesting theory. We will allocate a simplified definition of time which says that time is actually movement in space.

It can also be explained as a period of time considered as resources under your control and sufficient to accomplish a given activity task. It is the period during which actions or processes take place-Webster's Collins dictionary calls time as a system or measuring duration. A scarce resources which must be properly and sagaciously managed otherwise nothing can be managed. The continuum of experience in which events pass from the future through the present to the pass. The supply of time is very' limited, while the demand for it is limitless. Time is life. To waste your time therefore is to have wasted one's life.

Time management; Reed defined by Mehran, Hamid and Leila, (2015), management as the organizational process that includes managing resources, strategic planning, setting; objectives, employing and deploying the financial and human assets needed to achieve objectives, and measuring results. As defined by Elham, Mehdi and Seyed, (2014), time management is basically the art of arranging business and personal affairs in such a way that you together with your things show up when, where, and how you have intended them to as effortlessly and ubiquitously, as practicable, and to facilitate getting things done as promptly as practicable with the less amount of resources (money, time, energy and people) necessary.

Time management actually represents the tool, skills and abilities required in doing the right thing at the right time, with minimum effort, and resources, effectively and efficiently, leading to the achievement of your goals and the things you personally prioritized and value. Time management according to Jeremy, Teresa, Steven, Richard and Terri, (2013), is the organization of tasks or events by first estimating and forecasting how much a task would take to be completed, when exactly it must be completed and adjusting events that would interfere with its completion, so that completion is finally reached in the appropriate anticipated amount of time. Time management is not about getting more things done in a day. $\mathrm{ft}$ is rather about getting the things that matter most done. It is the ability to responsibly decide what is important in life both at work, at home and even one's personal life. Time management is not and would not ever be distinct and separable from management in general. Its main objective is to prevent dawdling and waste of time and regulate working time. Time management places much emphasis on preventing unnecessary activities, increase of efficiency, organizing and delegating tasks (James, 2016).

Effective time management provides employees with a feeling of greater security, independence and tire clients with satisfaction with efficient and faster service delivery tailored to the needs According to Ahlam, (2015), time management is about determining what should be done by first and foremost setting goals, deciding which events are considered most important and realizing that other activities or events will have to be scheduled around them (prioritizing), making decisions about how much time one allows for certain tasks (time estimation), flexibly adjusting to cater for the unexpected (problem solving), reconsidering priorities and goals on a regular basis (evaluation), and observing patterns and trends in behavior.

There is ongoing debate over exactly what skills and behaviors constitute effective time management. For example, Shipman identified six principles for effective time management. These principles included being aware of self, setting goals and priorities, structuring time appropriately increasing personal effectiveness and efficiency, scheduling time for events or activity, and scheduling relaxation time. Time management behaviors have more recently been characterized as making lists, organizing, evaluating one's schedule, goal setting, keeping and routinely breaking down tasks and events into simpler parts (Zahid, Saba, Pervez and Shahabuddin, 2014).

An empirical study investigating the effects of time management behavior has identified three broad most important clusters of behaviors. These behaviors include engaging in the mechanics of time management, setting goals and priorities, and having a preference for organization (Bagheri\&Yousefinezhad, 2012). However, seven time management skills or behaviors can be considered essential to effective time management due to their frequency or repetitive prominence in the literature:

- Time analysis,

- Planning,

- Goal setting,

- Prioritizing,

- Scheduling,

- Organizing, and

- Establishing new and improved time habits.

Although, time management documentation activities such as writing down goals, making lists, and utilizing calendars have been identified by many authors as necessary for effective time management, they tend to cross or fall in line with all seven skill areas mentioned above Mehran, Hamid and Leila, (2015),

In time management, prioritization which involves determining what one should do by setting goals, deciding 
which events are the most important and realizing that other activities or events will have to be scheduled around them; three workload categorization dimensions easily come to mind. They include, essential tasks, important tasks and low value tasks. It therefore takes the professionalism and organizational competence of the individual manager to appropriately and accordingly prioritize the given tasks by asking these three fundamental questions; which tasks are most valuable to the organization? Which task does my manager consider most important? And if I cannot complete all the tasks which should I complete? The need to help staff get organized thereby contributing to the stress reduction, freeing up time to do other activities and increasing work performance and productivity has been more vigorously stressed in recent time than ever (Bagheri\&Yousefinezhad, 2012).

\subsubsection{General Principles of Time Management}

Time management is a set of skills that assists people in using time effectively. There are general guidelines that can be employed for time management in different fields such as house, school, and job. A number of these guidelines are provided here. Initially, the reasons of not using tie management and the benefits derived from time management are studied. Probably, the most obvious reason for not using the time management is that people are not concept 'time management'. The second reason is laziness. Some people lack any effective target and required motivation for effective planning. The third group who do not make use of time management is the ones who tend to work under the pressure conditions (SadegGorji, 2016).

It is probable that not using of time management is justifiable, but successful usage of time management rejects any justified reason. Time management helps people in determining what task get priority over the others. Also, tie management assists people to increase the real work time through removing inessential activities. One of the satisfactory aspects of time management is reducing stress in life. Decrease of stress level leads to increased physical and spiritual health (Makenzi, 2006).

In general, organizational effectiveness is regarded as attaining the priorities and multidimensional goals within the common valuable framework so that achieving goals is efficient in terms of time and expense. Effectiveness involves the extent to which the organization provides its goals using specific resources and without wasting its sources in relation to the members and its community. In fact, organizational effectiveness shows one degree of closeness of organization in relation its goals. It is the extent to which organization develops as targets (Tofigiet al., 2011), Organizational effectiveness. Generally speaking, determining effectiveness in organization is not easy and different indexes as well as methods have been provided for evaluating and measuring the performance of organization. Developing qualification would lead to effectiveness of working time and that the increase of working time effectiveness would improve the effectiveness of organization.

In fact, inner satisfaction, joy and motivating are among the incentive-providing factors in employers that can be contributive to efficiency. Organizational effectiveness plays an important role in organizational development. Effective organization is said to be the one which is able to manage ambiguities, flexibilities, client-attracting, and production, valuing and starting. Experts have defined organizational effectiveness as tire extent to which one attains the determined goals, Peter Draker (2014) regards organizational effectiveness as a proper task and takes it into account as the key to success on the part of organization (SeyedNagavi, Narimani, and GhalamHoseini, 2010).

\subsubsection{Organizational Effectiveness}

The composition of people who formulate independent business identity for some specific purpose is commonly termed organization, and the process of getting desired outcome within defined resources is referred to as efficiency. Organizational efficiency is therefore the notion of how effectual an organization is in accomplishing the results the organization aims to generate. It plays a crucially important role in accelerating organizational development. It is said to be the net satisfaction of all constituents or elements in the process of gathering and transforming inputs into output in an efficient manner (Bagheri and Yousefinezhad, 2012).

Organizational efficiency is defined as the extent to which an organization, by the use of certain resources, fulfils its objectives or desired goal without depleting its resources and without placing undue strain on its members and/or society. It is the maximum combined utility of the primary constituents. The goal model describes organizational efficiency by the extent to which an organization attains its goals or objectives. The legitimacy model regards organizational efficiency focusing on a background evaluation 'of component preferences for performance and natural limitations on performance from a purely external environmental perspective'(James, 2016).

\subsection{Theoretical Framework}

The study was anchored on the Resource Base View Theory and Human Capital Theory.

\subsubsection{Resource Based View Theory}

Resource Based View (RBV) was articulated into a coherent theory by Wemerfelt (2014). The theory states that the organizational resources and capabilities that are rare, valuable, non- substitutable, and imperfectly imitable form the basis for a firm's sustained competitive advantage. RBV suggests that the firm can secure a sustained competitive advantage through facilitating the development of competencies that are firm specific, produce complex social relationship; are embedded in a firm's history and culture, and generate tacit organizational knowledge (Odhong, 2013). This theory recognizes manpower as the most valuable, non- substitutable and imperfectly imitable resource that a firm can successfully utilize to achieve organizational productivity and competitiveness. Resource-based theory is linked to human capital theory in that they both emphasize that investment in people adds to their value to the firm, (Baron and 
Armstrong, 2007).

\subsubsection{Human Capital Theory}

The origin of human capital goes back to emergence of classical economics in (1776) and thereafter developed a scientific theory. The idea of investing in human capital was first developed by Adam (1776), who argued in the Wealth of Nations that differences between the ways of working of individuals with different levels of education and training reflected differences in the returns necessary to defray the costs of acquiring those skills. Economists such as Elliot (1991) developed the theory of human capital. He is concerned with human capital in terms of the quality, not quantity, of the labor supply. After the manifestation of that concept as a theory, Schultz (1961) recognized the human capital as one of the important factors of national economic growth in the modem economy, (Dae-bong, 2009).

The theory argues that a person's formal education determines his or her earning power. Human capital theory holds that it is the key competences, skills, knowledge and abilities of the workforce that contributes to organizations competitive advantage. It focuses attention on resourcing, human resource development, and reward strategies and practices,

According to Human Capital Theory, education is an investment because it is believed that it could potentially bestow private and social benefits. Human capital theorists believe that education and earning power are correlated, which means, theoretically, that the more education one has, the more one can earn, and that the skills, knowledge and abilities that education provides can be transferred into the work in terms of productivity (Wabara, Sampson and Okwudili, 2017).

\subsection{Empirical Framework}

Mehran, Hamid and Leila, (2015), opined that time management is taken into account as an indispensable essence that is needed to get succeeded throughout the life. Time is the only source to be spent by a constant rate. It is crucial that people know how to make use of their time. Every thought and accomplishment requires time and every factor which needs time can be regarded as potentially wasting it. Every time wasters can generate psychological pressure. So, true understanding of the factors which waste out time is important so that one can make use of time in an efficient way leading to improving productivity. The study was survey-based in terms of the design. The main instrument used to collect the data was questionnaire and reliability was obtained as 0.978 using Cronbach alpha coefficient. Data analyses were done using SPSS software. The statistical population comprises of all employers working at Urmia Tax Administration and 278 people were chosen as the statistical sample. The aim of the present study was to investigate the effect of time management on increasing efficiency in organization. Findings of the study revealed that tendency to success, lack of rush in affairs, planning in affairs, skills in affairs, and preserving strict status in affairs can contribute to effectiveness of organization as $21.6 \%, 18.6 \%, 10 \%, 19.9 \%$, and $25.9 \%$, respectively.

Elham, Mehdi and Seyed, (2014), investigated the relationship between time management and organizational effectiveness and the stress coping styles employed by employees of sport and youth directorate of Alborz province. This was a descriptive co relational study done through field study. The sample included all employees of sport and youth directorate of Alborz province, 140 employees completed the questionnaires. The measuring instruments of this study included Macan time management scale (1950), Hsu organizational effectiveness scale (2002) and Endler and Parker stress coping styles (1990). The results of Pearson correlation coefficient tests and multiple regression showed that there was meaningful relation between stress coping styles and time management among male employees, however, there was no meaningful relation between the stress coping styles and organizational effectiveness. Furthermore, the best predictor of stress coping styles is time management. Among female employees, there is no meaningful relation between stress coping styles, time management and organizational effectiveness. Moreover, time management and organizational effectiveness do not predict the stress coping styles. Within the employees, from time management and organizational effectiveness, targeting is meaningfully able to predict stress coping styles.

Jeremy, Teresa, Steven, Richard and Terri, (2013), examined the efficacy of a new time management intervention designed for high school students. In both studies, there was no difference between the treatment and control groups in improvement in self-reported time management skills as a result of the intervention. However, the treatment group reported significantly greater improvement than the control group for secondary outcomes such as stress (Studies 1 and 2), anxiety (Studies 1 and 2), depression (Study 1), and knowledge of time management strategies (Study 1). Additionally, advisor ratings of student time management skills were higher for the treatment than for the control group in Study 2. Implications and suggestions for improving the intervention were discussed.

impact on employee productivity and by increasing the use of time management, employee productivity increases.

James, (2016), determined and identified the factors that affected time management in Ghana and examining the relationship between organizational effectiveness and time management. The model was designed based on the literature, linking factors of time management with time management and organizational effectiveness. Four hypotheses were built based on the literature and the model were tested in perspective of the previous studies and literature. The literature and various studies concluded that factors such as strategic planning, organizing/prioritizing and personal responsibility/accountability as principal indices of time management cumulatively had positive impact on organizational effective performance. The more these important time management principles or indices are employed by any organization or management, the more efficient and effective their time management practice becomes. Also there existed a positive relationship between time management and organizational Effectiveness. The more efficiently time was managed by the staff and employees of an organization, the more productive and effective the organization becomes. 


\section{Methodology}

\subsection{Research Design}

This researcher adopted the survey design which suits the research due its descriptive nature.

\subsection{Sources of Data}

Both primary and secondary source of data were utilized in gathering the information relevant for this work.

- Primary data: Primary data consisted of the use of questionnaire.

- Secondary data: Secondary data were also used in this work. Some of the secondary sources utilized included textbooks, seminar paper and related articles in academic journals and from the internet.

\subsection{Population of the Study}

The population of the study comprised eighty-five (85) staff of Total Nigerian plc. Aba (Field Survey, 2020).

\subsection{Sample Size Determination}

The researcher derived the sample size statically by using Taro Yamani (Abdullahi, 2012) as follow;

Using the formula;

$\mathrm{n}=\frac{N}{1+N(e) 2}$ Where;

$\mathrm{n}=$ Sample size

$\mathrm{N}=$ Population $(85)$

e = Margin of error (0.05) Thus, the sample size is:

$\mathrm{n}=\frac{85}{1+85(0.05) 2}$

$\mathrm{n}=\frac{85}{1+85(0.0025)}$

$\mathrm{n}=\frac{85}{1+0.21}$

$\mathrm{n}=\frac{85}{1.21}$

$\mathrm{n}=70$ Staff.

Therefore, the sample size for this study is 70 staff.

\subsection{Sampling Technique}

This researcher adopted simple random sampling technique which made it possible for all the workers to have equal opportunity of being selected as the representative sample based on the total population of the two hundred and ten, a normal confidence level of $95 \%$ and error tolerance of $5 \%$ was used.

\subsection{Description of the Instrument}

The instrument for collection of data for this research study was questionnaire, as this was used to obtain the necessary data from the respondents. The extent of existence for all variables in the research area was measured on a fivepoint Likert scale ranging from Undecided to Strongly Agree, ranging from 0-4. Where Undecided (UD) =0; Strongly Disagreed $(S D)=1$; Disagreed $(D)=2$, Agree $(A)=3$ and-Strongly Agree $(S A)=4$.

\subsection{Reliability of the Instrument}

The researcher used Test-Retest reliability to test the consistency of different administrations and also to determine the coefficient reliability of this research. Twenty (20) questionnaire were given to a set of respondents and obtained result. At interval of two weeks, 20questionnaires were administered to another set of respondents where the results obtained were the same as that of the first groups, hence the reliability of the research instrument.

\subsection{Method of Data Analyses}

Data for the study were analyzed using frequency distribution table, and percentages were used to analyze the data from the questionnaire, while simple regression and correlation with the use of SPSS were used to analyze the hypotheses.

\subsection{Data Presentation/Results and Discussion}

A total number of seventy (70) questionnaire were issued out by the researcher to Total Nigerian plc. Aba. The table below presents the distribution of the questionnaire to the sampled respondents. The generated data was presented and analyzed in the subsequent sub-heading below. 


\begin{tabular}{|c|c|c|}
\hline Total copies of Questionnaire & Respondents & Percentage (\%) \\
\hline Total distributed & 70 & 100 \\
Total valid returned & 62 & 88.6 \\
\hline Total invalid returned & 2 & 2.9 \\
Total not returned & 6 & 8.6 \\
\hline Total & 70 & 100 \\
\hline
\end{tabular}

Table 1: Distribution of Questionnaire and Response Rate

Source: Field Survey, 2020

\begin{tabular}{|c|c|c|}
\hline Status & No of respondents & Percentage (\%) \\
\hline Manager & 1 & 1.4 \\
\hline Pump attendants & 18 & 25.7 \\
\hline Security & 5 & 7.1 \\
\hline Customers & 46 & 65.7 \\
\hline Total & 70 & 100 \\
\hline
\end{tabular}

Table 2: Distribution of Respondents by Status in the Corporation

Source: Field Survey, 2020

\section{Results and Discussion}

Regression results showing the relationship between managerial planning/scheduling and profitability of Tonimas Nigerian plc. Aba.

\begin{tabular}{|c|c|c|c|c|c|}
\hline \multicolumn{5}{|c|}{ Model Summary $^{\mathbf{b}}$} \\
\hline Model & $\mathrm{R}$ & R Square & $\begin{array}{c}\text { Adjusted R } \\
\text { Square }\end{array}$ & $\begin{array}{c}\text { Std. Error of the } \\
\text { Estimate }\end{array}$ & Durbin-Watson \\
\hline 1 & $.907^{\mathrm{a}}$ & .823 & .817 & .44754 & .507 \\
\hline
\end{tabular}

\section{Table 3}

a. Predictors: (Constant), Goal Formulation and Achievement Contributes to the Profitability of TOMIMAS Nig. Ltd, Time Planning Increases Profitability of TONIMAS Nig. Ltd

b. Dependent Variable: to What Degree Does Product Scheduling Impact on the Profitability of TONIMAS Nig. Ltd

\begin{tabular}{|c|c|c|c|c|c|c|}
\hline \multicolumn{7}{|c|}{ ANOVA $^{a}$} \\
\hline & odel & Sum of Squares & $\mathrm{df}$ & Mean Square & $\mathrm{F}$ & Sig. \\
\hline \multirow[t]{3}{*}{1} & Regression & 54.957 & 2 & 27.478 & 137.191 & $.000^{\mathrm{b}}$ \\
\hline & Residual & 11.817 & 59 & .200 & & \\
\hline & Total & 66.774 & 61 & & & \\
\hline
\end{tabular}

Table 4

a. Dependent Variable: To what degree does product scheduling impact on the profitability of TONIMAS Nig. Itd b. Predictors: (Constant), Goal formulation and achievement contributes to the profitability of TOMIMAS Nig. Ltd, Time planning increases profitability of TONIMAS Nig. Ltd

\begin{tabular}{|c|c|c|c|c|c|c|}
\hline \multicolumn{7}{|c|}{ Coefficients $^{\mathbf{a}}$} \\
\hline \multirow{2}{*}{\multicolumn{2}{|c|}{ Model }} & \multicolumn{2}{|c|}{$\begin{array}{l}\text { Unstandardized } \\
\text { Coefficients }\end{array}$} & \multirow{2}{*}{$\begin{array}{c}\begin{array}{c}\text { Standardized } \\
\text { Coefficients }\end{array} \\
\text { Beta }\end{array}$} & \multirow[t]{2}{*}{$\mathrm{t}$} & \multirow[t]{2}{*}{ Sig. } \\
\hline & & B & Std. Error & & & \\
\hline \multirow[t]{3}{*}{1} & (Constant) & -.657 & .214 & & -3.074 & .003 \\
\hline & $\begin{array}{c}\text { Time planning increases } \\
\text { profitability of TONIMAS } \\
\text { Nig. Ltd }\end{array}$ & .602 & .146 & .497 & 4.137 & .000 \\
\hline & $\begin{array}{l}\text { Goal formulation and } \\
\text { achievement contributes } \\
\text { to the profitability of } \\
\text { TOMIMAS Nig. Ltd }\end{array}$ & .475 & .131 & .437 & 3.637 & .001 \\
\hline
\end{tabular}

\section{Table 5}

a. Dependent Variable: to What Degree Does Product Scheduling Impact on the Profitability of Tonimas Nig. Ltd

Interpretation

$\begin{array}{lc}\text { R } & =.907 \\ \text { R-Square } & =.823 \\ \text { Adjusted R-Square } & =.817 \\ \text { F - Statistic (df1=2 \& df2=59) } & =137.191 \\ \text { T Statistics } & =7.774\end{array}$


Table above showed the regression results between managerial planning/scheduling and profitability of TONIMAS Nig. Ltd Aba, Abia state. The regression results showed that the estimated coefficient of the regression parameter have a positive sign and thus conform to a-priori expectation. The implication of this sign was that the dependent variable profitability of TONIMAS Nig. Ltd Aba, Abia State, was affected by Goal formulation and achievement contributed to the profitability of TOMIMAS Nig. Ltd, Time planning increased profitability of TONIMAS Nig. Ltd and positively affected by degree of relationship between time management and organizational efficiency of TONIMAS Nig. Plc. Aba. The coefficient of determination R-square of 0.823 implied $82.3 \%$ of the sample variation in the dependent variable, degree of relationship between time management and organizational efficiency of TONIMAS Nig. Plc. Aba, was explained or caused by the explanatory variable while $17.7 \%$ is unexplained. This remaining $17.7 \%$ could be caused by other factors or variables not built into the model. The high value of R-square is an indication of a very good relationship between the dependent and independent variable. The value of the adjusted $R^{2}$ was 0.817 . This showed the regression line which captured $81.7 \%$ of the total variation in degree of relationship between time management and organizational efficiency of TONIMAS Nig. Plc. Aba was caused by variation in the explanatory variable specified in the model with 17.7 per cent accounting for the stochastic error term. The F-statistic was also used to test the overall significant of the model. The Fvalue of 137.191 was an indication that the model was statistically significant at 5 percent level of significant at degree of freedom df $1=2$ and $\mathrm{df} 2=59$.

\subsection{Test of Hypothesis}

\subsubsection{Hypothesis One}

- $\mathrm{H}_{0}$ : There is no positive and significant relationship between managerial planning/scheduling and profitability of TONIMAS Nig. Ltd Aba, Abia state.

$\mathrm{H}_{0}=\mathrm{B}_{1}=0$. Test the hypothesis that all slope coefficients were equal to zero.

$\mathrm{H}_{1} \neq \mathrm{B}_{1} \neq 0$. Test the hypothesis that not all slope coefficients were equal to zero.

With reference to table above, the calculated t-statistics of 7.774 was greater than the critical value (i.e.2.000), the null hypothesis was rejected and the alternative accepted. This means that there was positive and significant relationship between managerial planning/scheduling and profitability of TONIMAS Nig. Ltd Aba, Abia State.

\subsection{Findings}

The main objective of the study was to investigate the effect of time management on organizational efficiency with particular reference to TONIMAS Nig. Plc. Aba, Abia State. The major findings of the study can be summarized as follows;

There was significant relationship between managerial planning/scheduling and profitability of TONIMAS Nig. Ltd Aba, Abia State, as shown in3.10.2 where the result of the analysis revealed that the Calculated t-value of 7.774 was greater than the table value (2.000), therefore, the null $\left(\mathrm{H}_{0}\right)$ hypothesis was rejected, while the alternate hypothesis $\left(\mathrm{H}_{1}\right)$ accepted. This implies that there was significant relationship between managerial planning/scheduling and profitability of TONIMAS Nig. Ltd Aba, Abia state.

\section{Conclusion}

The empirical findings and analyses conducted in TONIMAS Nig. Ltd Aba, of Abia State showed that time management directly contributed to organizational efficiency. The significant correlation between different time management strategy and organizational efficiency, measured by using managerial planning/scheduling and organizational profitability which was also found in the relationship between the formality of managerial planning/scheduling, employee productivity and profitability in time management. Regarding the second approach to measuring the time management effectiveness and organizational efficiency (managerial responsibility and accountability) a significant correlation was found in the relationship between the time management and organizational efficiency. Hence, formality of time management has been shown as the most influential and impactful in organizational efficiency.

\section{Recommendations}

- First and foremost, the study recommend that any organization that desires high output efficiency (financially and non-financial wise) should endeavor to embrace the principles of time management which is embedded in managerial planning/scheduling.

- To avoid failure or the death of an organization, the managers of the organization should be committed to institutionalizing the practice of managerial planning/scheduling in its culture by ensuring that proper time management permeates every nook and cranny of the organization.

- There should be a proper allocation of time and adherence to improve efficiency in the organization.

\section{References}

i. Adebayo F. A., (2015). Time Management and Students Academic Performance in Higher Institutions, Nigeria-A Case Study of Ekiti State. 2015, Vol. 3, No. 2

ii. Adebisi, J., (2013). Time Management Practices and Its Effect on Business Performance. CanadianSocialScience,9(1),165-168Availablefrom: http://www.cscanada.net/index.php/css/article/ 
iii. Adeyinka A. (2012). Effective time management for high performance in an organization. Business School Degree programme in Business Administration International Business 2012.

iv. Ahmad N., Nizan A., Mohamed N., and Wahab, S. (2012). The Relationship between Time Management and Job Performance in Event Management. Social and Behavioral Sciences. Vol. 65, 2012: 937-941.

v. Amir E. E., and Saeed E., (2015). The Effect of Time Management on Human Resource Productivity Social Security Organization of Yazd Journal of Applied Environmental and Biological Sciences, 5(11S) 69-79, ISSN: 20904274www.textroad.com

vi. Ahlam M. E., (2015).Impact of Time Management Program on Time Wasters of Head Nurses and Their Perception toward Effective Organizational Performance. IOSR Journal of Nursing and Health Science (IOSR-JNHS) e-ISSN: 2320-1959.p- ISSN: 2320-1940 Volume 4, Issue 3 Ver. II (May. - Jun. 2015), PP 18-30 DOI: 10.9790/1959-04321830 www.iosrjournals.org

vii. Elham S., Mehdik., and Seyed M. B. (2014). The relation between time management and organizational effectiveness and stress coping styles of sport and youth directorate staffs. CODEN (USA): EJEBAU European Journal of Experimental Biology, 4(1): 203-210 ISSN: 2248 -9215 www.pelagiaresearchlibrary

viii. Hamdan S. A., and Samar Suleiman A., (2013).The Impact of Organizational Power Sources on Time Management from the Perspective of Governmental Departments' Managers in Al Balqa' Governorate. Faculty of Business, AL-Balqaa Applied University, Al-salt, Jordan.

ix. Hanan E. E., Wafaa F. S., and Hala G. E., (2015). Effect of Time Management Program on Job Satisfaction for Head NursesJournal of Education and Practice ISSN 2222-1735 (Paper) ISSN 2222-288X (Online)Vol.6, No.32, www.iiste.org

x. Hanan E. E., Wafaa F. S., and Hala G. E., (2015). Effect of Time Management Program on Job Satisfaction for Head Nurses Journal of Education and Practice ISSN 2222-1735 (Paper) ISSN 2222-288X (Online)Vo Zahid A. C., Saba S., Pervez A. P., and Shahabuddin M., (2014). Impact of time management on organizational performance. The Women - Annual Research Journal Vol. 6, 2014

xi. Wabara A. N., Sampson J. C., and Okwudili B. E., (2017). Effects of manpower development on organizational Efficiency: a study of Enugu electricity distribution company (EEDC) in Abia state, Nigeria (2014-2016)Global Journal of Arts, Humanities and Social SciencesVol.5, No.7, pp.39-51, August 2017 ISSN: 2052-6350(Print) ISSN: 2052-6369(Online) (www.eajournals.org)

xii. 1.6, No.32, www.iiste.org

xiii. James Z., (2016). Impact of Time Management on Organizational Effectiveness South American Journal of Management Volume 2, Issue 1, 